\title{
Persepsi Mahasiswa tentang Kesulitan yang Dihadapi Saat Menempuh JLPT: Studi Kasus Mahasiswa Program Studi Bahasa Jepang Sekolah Vokasi Universitas Gadjah Mada
}

\author{
Lufi Wahidati ${ }^{1}$, Dinar Rahmawati ${ }^{2}$ \\ Universitas Gadjah Mada ${ }^{1}$ \\ lufi.wahidati@ugm.ac.id \\ Wahana Gama Hashimoto ${ }^{2}$ \\ dinarrahmawati@gmail.com
}

\begin{abstract}
Japanese Language Proficiency Test (JLPT) is the largest-scale Japanese-Language test for non-native speakers in the world. This measurement tool is used by many companies and universities to assess the Japanese language skills of a job/scholarship applicant. The minimum standard expected by a company or university is the JLPT N3 level. Therefore, the majority of educational institutions in Indonesia that organize Japanese language programs set the learning outcome of its graduates to be equivalent to JLPT level N3. However, many students fail to pass the JLPT N3 exam before they graduate from college. In this study, a survey was conducted through a questionnaire to find out students' perceptions of the difficulties they encountered while taking the JLPT N3 exam. This study was conducted at the Japanese Study Program of the Vocational College of Uninversitas Gadjah Mada. Based on the results of the study, 88\% of respondents found difficulty in answering Reading (Dokkai) and $62 \%$ of respondents found difficulty in answering Grammar (Bunpo) questions. Only $41 \%$ of respondents found difficulty in answering Vocabulary (Moji-goi) questions. Meanwhile, 59\% of respondents found that the easiest exam questions were Listening (Choukai) questions. Generally, there are several factors that cause the difficulties. According to the students, the factor causing the difficulties in all types of questions (Reading, Grammar, Vocabulary and Listening) is the low mastery in vocabulary.
\end{abstract}

Keywords: competencies, JLPT, Japanese Language Proficiency Test, learners ' difficulties

\section{INTISARI}

Japanese Language Proficiency Test (JLPT) adalah salah satu alat ukur kompetensi bahasa Jepang bagi non-native speaker, yang paling banyak diikuti di seluruh dunia. Alat ukur ini digunakan oleh banyak perusahaan dan universitas untuk menilai kemampuan bahasa Jepang seorang pelamar (pekerjaan/beasiswa). Standar minimum yang diharapkan oleh perusahaan atau universitas adalah level JLPT N3. Oleh karena itu, sebagian besar instansi pendidikan yang menyelenggarakan program bahasa Jepang, menetapkan capaian pembelajaran lulusannya adalah setara dengan JLPT N3. Pada kenyataannya, banyak mahasiswa yang tidak berhasil lulus ujian JLPT N3 sebelum mereka lulus perguruan tinggi. Pada penelitian ini, dilakukan pendataan melalui angket tentang persepsi mahasiswa Program Studi DIII Bahasa Jepang Sekolah Vokasi UGM tentang kesulitan-kesulitan yang mereka hadapi pada saat mengambil ujian JLPT N3. Berdasarkan hasil penelitian, kesulitan saat mengerjakan kelompok soal Membaca (Dokkai) dirasakan oleh $88 \%$ responden dan kesulitan mengerjakan soal Tata Bahasa (Bunpo) dirasakan oleh $62 \%$ responden. Hanya $41 \%$ mahasiswa yang merasa kesulitan mengerjakan soal Kosakata (Moji-goi). Sementara itu, 59\% mahasiswa merasa soal 
ujian yang paling mudah adalah kelompok soal Menyimak (Choukai/Listening). Terdapat beberapa faktor penyebab kesulitan. Menurut mahasiswa, terdapat satu faktor penyebab kesulitan yang dirasakan pada seluruh jenis soal (Membaca, Tata bahasa, Kosakata dan Menyimak), yaitu faktor rendahnya penguasaan kosakata.

Kata kunci: kesulitan pembelajar, kompetensi, JLPT, Tes Kemampuan Bahasa Jepang

\section{PENDAHULUAN}

Di dunia kerja, keterampilan teknis (hard skill) sama pentingnya dengan keterampilan lunak (soft skill) seseorang. Keterampilan teknis seseorang berkaitan dengan pekerjaan utama pada bidang tertentu, misalnya bidang teknologi informasi, keuangan, kebahasaan atau bidang lainnya. Keterampilan teknis adalah keterampilan yang selalu ditulis di daftar riwayat hidup seseorang (CV) saat seseorang akan mencari pekerjaan, dan penguasaan keterampilan teknis tersebut pulalah yang menjadi pertimbangan sebuah instansi untuk menerima seseorang untuk bekerja di instansi tersebut.

Dewasa ini, meningkatnya kerja sama ekonomi antara Indonesia dan Jepang menyebabkan tingginya kebutuhan akan tenaga profesional dengan keterampilan teknis bahasa Jepang di industri dalam negeri maupun di Jepang. Tenaga profesional penutur bahasa Jepang yang memiliki keterampilan bahasa Jepang yang mumpuni menjadi incaran di sektor publik maupun sektor privat. Perusahaan biasanya menetapkan standar penguasaan keterampilan bahasa Jepang kepada para calon pelamar. Kompetensi bahasa Jepang dapat ditunjukkan dengan sertifikat kemampuan bahasa Jepang yang diperoleh setelah seseorang mengikuti ujian kemampuan bahasa Jepang. Dari berbagai jenis ujian kemampuan bahasa Jepang, Nihongo Nouryoku Shiken, atau lebih sering dikenal dengan nama Japanese Language Profeciency Test (JLPT), adalah ujian yang paling banyak dijadikan acuan untuk mengukur kompetensi bahasa Jepang seseorang.

Japanese Language Profeciency Test (JLPT) adalah salah satu alat ukur kompetensi bahasa Jepang seseorang yang paling banyak diikuti oleh pembelajar bahasa Jepang dan diakui di seluruh dunia. JLPT terdiri dari lima level yaitu dari level N1 (tertinggi) hingga level N5 (terendah). Untuk memasuki dunia kerja yang menuntut penguasaan keterampilan teknis bahasa Jepang, seseorang minimal dituntut untuk memiliki sertifikat JLPT N3 (Cahyono \& Syartanti, 2017). Oleh karena itu, institusi pendidikan yang menyelenggarakan program bahasa Jepang di jenjang perguruan tinggi menjadikan JLPT N3 sebagai standar kualifikasi kompetensi lulusannya.

Program Studi (Prodi) Diploma Bahasa Jepang Sekolah Vokasi UGM juga mewajibkan seluruh mahasiswanya untuk mengikuti JLPT N3. Mahasiswa Prodi Bahasa Jepang Sekolah Vokasi UGM yang mengikuti ujian JLPT level N3 pada tahun 2011 berjumlah 23 peserta, tahun 2012 berjumlah 34 peserta, dan pada tahun 2013 berjumlah 29 peserta. Jumlah peserta yang lulus pada masing-masing tahun tersebut sangat rendah, yaitu hanya 1 peserta pada tahun 2011 dan pada tahun 2012 juga 2013 masing-masing 2 peserta (Rahmawati, 2014). Rendahnya jumlah mahasiswa yang lulus JLPT N3 pada periode tersebut menunjukkan bahwa banyak mahasiswa yang merasa kesulitan dalam mengerjakan soal JLPT N3.

Kesulitan yang dirasakan oleh mahasiswa dalam mengerjakan soal JLPT menjadi penting untuk diteliti lebih jauh 
agar dosen dapat menemukan strategi yang tepat dalam menyelenggarakan kegiatan pembelajaran bahasa Jepang dan meningkatkan kualitas lulusan. Oleh karena itu, penelitian ini berusaha untuk menjelaskan kesulitan-kesulitan yang dirasakan oleh mahasiswa dalam menghadapi ujian JLPT N3.

\section{METODE PENELITIAN}

Penelitian ini dilakukan di Prodi Bahasa Jepang Sekolah Vokasi Universitas Gadjah Mada. Data dikumpulkan melalui angket secara daring yang disebarkan kepada mahasiswa yang telah mengikuti ujian JLPT N3 selama menjadi mahasiswa (antara tahun 2017-2019). Terdapat 34 mahasiswa yang mengisi angket terdiri dari mahasiswa semester VI (23 mahasiswa) dan semester IV (11 mahasiswa). Angket tersebut terdiri dari dua jenis pertanyaan, yaitu:

a. enam pertanyaan tertutup mengenai kesulitan yang dirasakan pada saat mengerjakan JLPT N3 berdasarkan kelompok soal (kosakata, tata bahasa, membaca, dan menyimak), dan

b. empat pertanyaan terbuka mengenai faktor penyebab kesulitan pada masing-masing kelompok soal JLPT N3.

Hasil angket direkapitulasi kemudian dianalisis lebih jauh untuk mendapatkan jawaban untuk permasalahan yang diteliti. Berdasarkan jawaban responden atas pertanyaan tertutup (a), dapat disimpulkan kelompok soal yang paling sulit menurut persepsi mahasiswa. Setelah itu, jawaban atas pertanyaan terbuka (b) dipilah-pilah kemudian dikelompokkan dalam kategori-kategori sehingga dapat ditemukan faktor-faktor penyebab kesulitan tersebut. Hasil analisis kemudian disajikan secara deskriptif.

\section{Karakteristik JLPT}

JLPT diselenggarakan pertama kali pada tahun 1984 oleh The Japan
Foundation (JF) dan Japan Educational Exchanges and Services (JEES) (sebelumnya dikenal dengan nama Association of Internasional Education Japan). Sejak tahun 1984-2008, ujian JLPT hanya diselenggarakan pada bulan Desember setiap tahunnya. Mulai tahun 2009, ujian diselenggarakan 2 kali dalam satu tahun, yaitu bulan Juli dan Desember. Pada awalnya hanya sekitar 7.000 peserta, namun pada 2011, ada lebih dari 610.000 peserta yang tersebar di 62 negara, dan melonjak hingga mencapai 1.168 .535 peserta dari 87 negara pada tahun $2019^{1}$. Jumlah ini menjadikan JLPT sebagai ujian bahasa Jepang dengan skala terbesar di dunia.

Berdasarkan data rekapitulasi peserta ujian JLPT pada bulan Desember tahun 2018, sebanyak $42,2 \%$ peserta ujian berasal dari kalangan pelajar dan $27,6 \%$ peserta berlatar belakang pegawai (guru/dosen, sektor publik, swasta, maupun wiraswasta). Selain untuk mengukur kemampuan bahasa Jepang sendiri $(33,2 \%)$, sebanyak $33,4 \%$ peserta mengikuti JLPT untuk kepentingan pekerjaan, baik untuk melamar pekerjaan, maupun untuk peningkatan karir dalam pekerjaan yang digeluti di negaranya sendiri maupun di Jepang.

Pihak penyelenggara JLPT (JF dan JEES) menyatakan bahwa JLPT memiliki karakteristik tersendiri, yaitu ujian ini tidak hanya mengukur pengetahuan tentang kosa kata dan tata bahasa Jepang tetapi juga mengukur kemampuan seseorang untuk menggunakan pengetahuan dalam komunikasi aktual saat melakukan berbagai "tugas sehari-hari" yang membutuhkan bahasa. Oleh karena itu, JLPT mengukur kompetensi komunikatif bahasa Jepang komprehensif melalui tiga elemen: (1) "pengetahuan bahasa" untuk mengukur pengetahuan tentang kosakata dan tata bahasa, serta (2) "membaca" dan (3) "menyimak" untuk mengukur kemampuan seseorang dalam

\footnotetext{
${ }^{1}$ https://www.jlpt.jp/e/statistics/index.html (diakses tanggal 2 Juli 2019)
} 
menggunakan pengetahuan dalam komunikasi aktual.

JLPT terdiri dari 5 level. Dari level tertinggi ke yang lebih rendah yaitu N1, N2, N3, N4, N5. Level terendah, level N4 dan N5 mengukur tingkat pemahaman bahasa Jepang dasar yang terutama dipelajari di kelas. Sementara itu, level N1 dan N2 mengukur tingkat pemahaman bahasa Jepang yang digunakan dalam berbagai situasi dalam kehidupan sehari-hari yang sebenarnya; sedangkan level N3 adalah tingkat penghubung antara N1/ N2 dan N4 / N5.
Dalam JLPT, kompetensi linguistik diukur melalui kegiatan bahasa, seperti Membaca dan Menyimak. Pengetahuan Bahasa, meliputi Kosakata dan Tata Bahasa, juga diperlukan untuk berhasil lulus pada ujian ini. Kompetensi yang diukur dalam JLPT pada masing-masing level dapat dilihat pada tabel 1 .
Adapun dalam pelaksanaannya, masing-masing level dibagi ke dalam beberapa sesi ujian dengan durasi yang berbeda-beda. Level N1 dan N2 terdiri dari 2 sesi ujian, sedangkan level N3, N4, dan N5 dibagi menjadi 3 sesi ujian sebagaimana dapat dilihat pada tabel 2 .

\section{Tabel 1. Kemampuan Linguistik Yang Dibutuhkan Untuk Lulus JLPT Per Level}

\begin{tabular}{|c|l|}
\hline Level & \multicolumn{1}{|c|}{ Kemampuan linguistik yang dibutuhkan untuk lulus } \\
\hline N1 & Kemampuan memahami bahasa Jepang digunakan dalam berbagai situasi. \\
\hline N2 & $\begin{array}{l}\text { Kemampuan untuk memahami bahasa Jepang yang digunakan dalam situasi sehari-hari, dan } \\
\text { dalam berbagai keadaan hingga tingkat tertentu. }\end{array}$ \\
\hline N3 & $\begin{array}{l}\text { Kemampuan untuk memahami bahasa Jepang digunakan dalam situasi sehari-hari hingga tingkat } \\
\text { tertentu. }\end{array}$ \\
\hline N4 & Kemampuan untuk memahami bahasa Jepang dasar. \\
\hline N5 & Kemampuan untuk memahami beberapa bahasa Jepang dasar. \\
\hline
\end{tabular}

(sumber: https://www.jlpt.jp/e/about/levelsummary.html)

Tabel 2. Pembagian Sesi Ujian Per Level

\begin{tabular}{|c|c|c|c|}
\hline Level & \multicolumn{3}{|c|}{ Sesi ujian \{durasi ujian\} } \\
\hline N1 & \multicolumn{2}{|c|}{$\begin{array}{l}\text { Pengetahuan bahasa (kosakata/tata bahasa) } \\
\text { dan membaca }\{110 \text { menit }\}\end{array}$} & $\begin{array}{l}\text { Menyimak } \\
\{60 \text { menit }\}\end{array}$ \\
\hline N2 & \multicolumn{2}{|c|}{$\begin{array}{c}\text { Pengetahuan bahasa (kosakata/tata bahasa) } \\
\text { dan membaca }\{105 \text { menit }\}\end{array}$} & $\begin{array}{l}\text { Menyimak } \\
\{50 \text { menit }\}\end{array}$ \\
\hline N3 & $\begin{array}{l}\text { Pengetahuan bahasa (kosakata) } \\
\qquad\{30 \text { menit }\}\end{array}$ & $\begin{array}{l}\text { Pengetahuan bahasa (tata bahasa) dan } \\
\text { Membaca }\{70 \text { menit }\}\end{array}$ & $\begin{array}{l}\text { Menyimak } \\
\{40 \text { menit }\}\end{array}$ \\
\hline N4 & $\begin{array}{l}\text { Pengetahuan bahasa (kosakata) } \\
\qquad\{30 \text { menit }\}\end{array}$ & $\begin{array}{l}\text { Pengetahuan bahasa (tata bahasa) dan } \\
\text { Membaca }\{60 \text { menit }\}\end{array}$ & $\begin{array}{l}\text { Menyimak } \\
\{35 \text { menit }\end{array}$ \\
\hline N5 & $\begin{array}{l}\text { Pengetahuan bahasa (kosakata) } \\
\qquad\{25 \text { menit }\}\end{array}$ & $\begin{array}{l}\text { Pengetahuan bahasa (tata bahasa) dan } \\
\text { Membaca }\{50 \text { menit }\}\end{array}$ & $\begin{array}{l}\text { Menyimak } \\
\{30 \text { menit }\}\end{array}$ \\
\hline
\end{tabular}

(sumber: https://www.jlpt.jp/e/guideline/testsections.html)

\section{Komposisi Soal JLPT N3}

Penelitian ini membahas mengenai persepsi mahasiswa atas kesulitan yang di hadapi saat menempuh ujian JLPT level N3. Level ini adalah level yang biasanya dijadikan syarat minimal bagi seseorang untuk melamar pekerjaan di perusahaan/instansi tertentu atau untuk mendapatkan beasiswa program pertukaran mahasiswa di universitas di Jepang.

Seperti yang dapat dilihat pada tabel 1, kompetensi linguistik yang diperlukan untuk lulus JLPT N3 adalah kemampuan untuk memahami bahasa Jepang yang digunakan dalam situasi sehari-hari hingga tingkat tertentu. Jika seseorang telah lulus JLPT N3, diasumsikan dia telah menguasai bahasa 
Jepang dasar dengan baik dan mampu menggunakannya untuk berkomunikasi sehari-hari namun masih terbatas pada situasi tertentu saja.

JLPT N3 dibagi menjadi 3 sesi ujian. Sesi pertama adalah ujian pengetahuan bahasa (kosakata), sesi ke-2 adalah ujian pengetahuan bahasa (tata bahasa) dan membaca, sedangkan sesi ke-3 adalah ujian menyimak. Berikut ini adalah komposisi soal pada JLPT N3.

1. Pengetahuan bahasa:

a. Kosakata (moji-goi):

1) membaca kanji;

2) ortografi (ejaan): menentukan penulisan huruf kanji yang tepat dari sebuah kata;

3) parafrase: menentukan sinonim kata yang tepat sesuai dengan konteks kalimat;

4) penggunaan kosakata tertentu dalam konteks kalimat.

b. Tata Bahasa (bunpou):

1) memilih pola tata bahasa yang tepat;

2) komposisi kalimat: mengurutkan kata yang diacak sehingga menjadi kalimat yang benar;

3) melengkapi teks dengan pola tata bahasa yang tepat.

2. Membaca (dokkai):

1) memahami isi bacaan pendek;

2) memahami isi bacaan sedang;

3) memahami isi bacaan panjang; dan

4) memahami isi pengumuman.

3. Menyimak (choukai):

1) pemahaman berbasis tugas (task based comperhension): kemampuan memahami apa yang harus dilakukan selanjutnya oleh tokoh tertentu setelah mendengarkan percakapan dalam soal;

2) memahami poin utama dialog/ceramah: kemampuan memahami hal yang perlu diperhatikan (hitsuyou na tokoro) dalam sebuah dialog;

3) memahami garis besar percakapan secara umum: kemampuan memahami percakapan secara keseluruhan;

4) memahami ekspresi verbal; dan

5) mampu merespon percakapan dengan cepat dan tepat.

Dari empat kelompok soal tersebut (kosakata, tata bahasa, membaca, dan menyimak), kelompok soal dan jenis soal yang paling sulit menurut mahasiswa berdasarkan hasil angket, akan dibahas pada bagian berikut.

\section{HASIL DAN PEMBAHASAN}

Angket mengenai persepsi mahasiswa tentang kesulitan yang dihadapi saat menempuh ujian JLPT level N3 telah disebarkan kepada mahasiswa. Responden penelitian berjumlah 34 mahasiswa (lihat tabel 3) dan seluruhnya pernah mengikuti ujian JLPT N3. Dari 34 mahasiswa tersebut, $50 \%$ telah lulus JLPT N3 dan 50\% responden menyatakan belum berhasil lulus JLPT N3. Dari 50\% responden yang telah lulus JLPT N3, sebanyak 14 mahasiswa $(82 \%)$ adalah mahasiswa semester VI, namun mereka lulus JLPT N3 pada tahun yang berbeda-beda. Sejumlah satu orang telah lulus JLPT N3 pada semester I, enam mahasiswa lulus pada semester III, empat mahasiswa lulus pada semester IV, dan tiga mahasiswa lulus di semester V.

Tabel 3. Data Responden

\begin{tabular}{|c|c|c|c|c|c|c|c|c|}
\hline \multirow{2}{*}{$\begin{array}{c}\text { Tahun } \\
\text { masuk } \\
\text { universitas }\end{array}$} & \multirow[t]{2}{*}{ Keterangan } & \multicolumn{5}{|c|}{$\begin{array}{l}\text { Jumlah peserta ujian } \\
\text { berdasarkan semester }\end{array}$} & \multirow[t]{2}{*}{ Subtotal } & \multirow{2}{*}{$\begin{array}{c}\text { Total } \\
\text { responden }\end{array}$} \\
\hline & & I & II & III & IV & $\mathbf{V}$ & & \\
\hline \multirow{2}{*}{2017} & lulus & 1 & - & 6 & 4 & 3 & 14 & \multirow{4}{*}{34} \\
\hline & tidak lulus & - & - & 1 & - & 8 & 9 & \\
\hline \multirow{2}{*}{2018} & lulus & - & 1 & 2 & - & - & 3 & \\
\hline & tidak lulus & - & - & 8 & - & - & 8 & \\
\hline
\end{tabular}

(sumber: data penelitian tahun 2019) 
Sementara itu, 18\% lainnya adalah mahasiswa semester IV yang terdiri dari satu mahasiswa yang lulus pada semester II, dan dua mahasiswa yang lulus pada semester II sedangkan 50\% mahasiswa yang belum lulus JLPT N3 terdiri dari sembilan mahasiswa semester VI dan delapan mahasiswa semester IV.

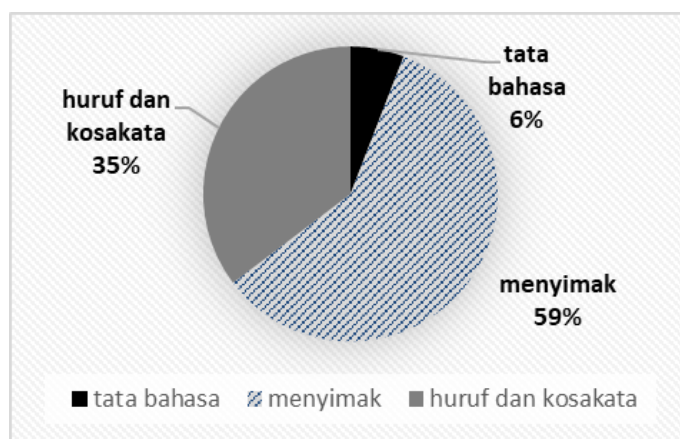

Bagan 1. Jenis Soal Yang Paling Mudah Menurut Mahasiswa

(sumber: data penelitian tahun 2019)

Berdasarkan hasil angket yang dituangkan dalam bagan 1, terdapat 59\% mahasiswa menyatakan bahwa dari 4 kelompok soal JLPT N3, kelompok soal Menyimak adalah yang paling mudah. Sementara itu, terdapat $35 \%$ responden yang memilih kelompok soal Kosakata, dan 6\% responden yang memilih kelompok soal Tata Bahasa sebagai kelompok soal yang paling mudah. Tidak satu responden pun menyatakan kelompok soal Membaca sebagai yang termudah.

\section{Kelompok Soal yang Dirasa Sulit}

Berkaitan dengan penyebab kegagalan dalam ujian, seluruh responden yang belum berhasil lulus JLPT N3 menyatakan bahwa mereka merasa kurang menguasai materi ujian sehingga merasa kesulitan saat mengerjakan soal ujian dan berujung pada ketidaklulusan mereka.

Pada Bagan 2, dapat diketahui kelompok soal JLPT N3 yang dirasa sulit menurut persepsi mahasiswa. Sebanyak $88 \%$ responden merasakan kesulitan saat mengerjakan kelompok soal Membaca.
Berikutnya, kesulitan mengerjakan soal tata bahasa dirasakan oleh $62 \%$ responden. Sementara itu, persentase responden yang merasa kesulitan mengerjakan kelompok soal Kosakata dan Menyimak tidak setinggi kedua kelompok soal Membaca dan Tata Bahasa, yaitu sebesar $41 \%$ untuk kelompok soal Kosakata dan hanya $12 \%$ untuk kelompok soal Menyimak.

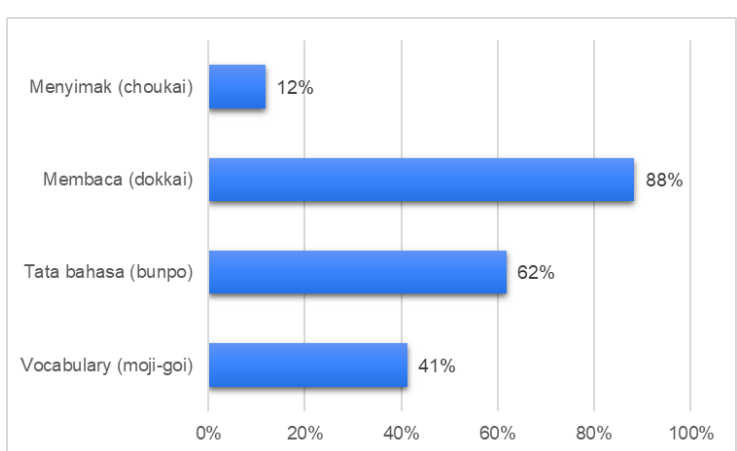

Bagan 2. Kelompok Soal yang Dirasa Sulit (sumber: data penelitian tahun 2019)

\section{Kesulitan Pada Kelompok Soal Membaca dan Faktor Penyebabnya}

Kendala terberat yang dihadapi oleh mahasiswa saat mengerjakan soal JLPT N3 adalah kelompok soal Membaca. Keterampilan membaca memang merupakan keterampilan bahasa yang cukup sulit. Babaiba Medjahdi (2014) mengungkapkan bahwa "reading is considered as the most difficult language skill, which involves the interaction of multiple cognitive, metacognitive, linguistic and sociolinguistic aspects. i.e.; some other sub-Skills operate all together in order to perform the task." Keterampilan membaca menuntut berbagai kompetensi kognitif seseorang diaktifkan pada saat bersamaan, sehingga tidak mengherankan jika membaca menjadi kendala utama para pembelajar bahasa asing, tak terkecuali pembelajar bahasa Jepang di Sekolah Vokasi Universitas Gadjah Mada.

Pada Bagan 3, dapat dilihat bahwa terdapat 30 mahasiwa $(88 \%)$ yang mengungkapkan bahwa pada kelompok 
soal Membaca, bagian soal bacaan panjang adalah yang tersulit. Setelah satu bacaan panjang biasanya terdapat empat soal yang harus dikerjakan. Jika mahasiswa kesulitan untuk memahami isi bacaan, maka mereka akan kehilangan kesempatan untuk mendapatkan poin dari empat soal tersebut.

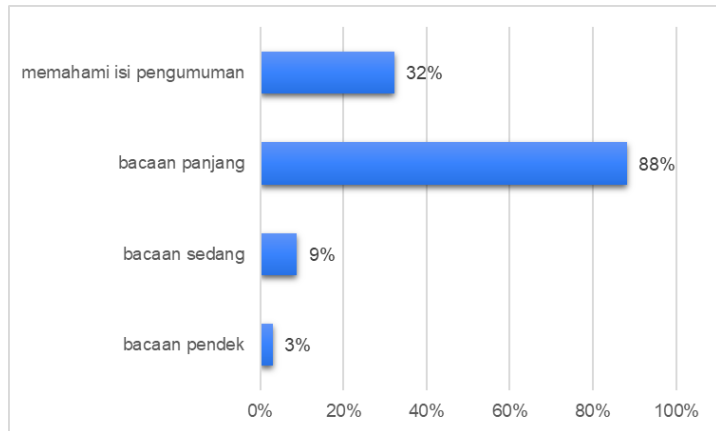

Bagan 3. Bagian Tersulit dalam

Kelompok Soal Membaca

(sumber: data penelitian tahun 2019)

Kesulitan pada kelompok soal Membaca berikutnya dirasakan oleh 38\% mahasiswa yaitu saat mengerjakan soal memahami isi pengumuman. Dalam setiap level JLPT pada kelompok soal Membaca, pasti terdapat bacaan berupa pengumuman/pamflet/brosur. Pada level $\mathrm{N} 3$, terdapat dua soal yang menuntut peserta untuk dapat memahami informasi penting yang terdapat dalam satu bacaan pengumuman. Tipe bacaan ini biasanya menggunakan bahasa yang singkat, padat, serta banyak digunakan gabungan kanji (jukugo). Selain itu, pada bacaan pengumuman biasanya tertulis informasi tambahan berupa syarat atau pengecualian yang kadang terabaikan oleh peserta ujian. Oleh karena itu, bagian soal ini menuntut kehati-hatian dan ketelitian peserta ujian.

Sementara itu, hanya sedikit yang merasa kesulitan saat mengerjakan bacaan sedang (9\%) dan bacaan pendek (3\%). Satu bacaan sedang diikuti tiga soal, dan satu bacaan pendek hanya diikuti satu soal. Bacaan pendek dan bacaan sedang biasanya hanya terdiri dari dua sampai tiga paragraf, dengan jumlah kalimat yang lebih banyak pada bacaan sedang. Hal ini memungkinkan peserta ujian untuk membaca ulang bacaan hingga menemukan jawaban yang menurut mereka benar tanpa merasa kehabisan waktu. Tentu berbeda dengan bacaan panjang yang cenderung membuat grogi dan tidak tenang jika harus mengulang-ulang membaca karena akan membuat peserta merasa kekurangan waktu untuk mengerjakan bagian soal lainnya.

Menurut persepsi mahasiswa, terdapat beberapa faktor yang menyebabkan kesulitan dalam mengerjakan kelompok soal Membaca. Faktor pertama yaitu penguasaan kosakata yang kurang. Sebanyak 19 mahasiswa (55\%) mengungkapkan bahwa dalam bacaan, mereka menemukan banyak kosakata yang belum pernah mereka kenal sebelumnya. Sebagai tambahan, sebagian kecil mahasiswa juga mengungkapkan bahwa banyak terdapat huruf kanji/gabungan kanji yang belum pernah dipelajari sebelumnya.

Faktor penyebab kesulitan kedua adalah banyak terdapat kalimat yang panjang dan menyebabkan mahasiswa kesulitan untuk memahami intinya. Faktor kesulitan ini dirasakan oleh $38 \%$ responden. Hal ini mungkin dikarenakan dalam bacaan banyak digunakan kalimat majemuk. Kalimat majemuk yang panjang, terdiri dari dua klausa dan terdapat lebih dari satu subjek maupun predikat dalam satu kalimat. Bahkan dalam bacaan panjang, tidak jarang terkandung kalimat kompleks (kalimat majemuk yang bertingkat-tingkat). Kalimat kompleks minimal terdiri dari tiga klausa dan mengandung lebih dari satu induk/anak kalimat (Tjandra, 2014). Kerumitan struktur kalimat majemuk dan kalimat kompleks membuat para siswa kesulitan menangkap inti kalimat. Faktor ini diperkirakan berakar dari rendahnya pemahaman tentang struktur 
pembentukan kalimat dan tata bahasa Bahasa Jepang.

Beberapa faktor penyebab lainnya yang diungkapkan oleh mahasiswa di antaranya adalah faktor kurangnya waktu, terdapatnya pola tata bahasa yang belum dipahami maknanya, serta faktor mengantuk saat mengerjakan. Faktor kurangnya waktu yang dirasakan oleh beberapa mahasiswa mungkin juga disebabkan oleh faktor-faktor lain yang telah disebutkan sebelumnya. Peserta ujian pasti akan kehabisan waktu untuk memahami isi bacaan apabila terdapat kendala saat membaca teks, bisa jadi karena penguasaan kosakata yang minim atau karena pemahaman tata bahasa yang masih rendah.

\section{Kesulitan Pada Kelompok Soal Tata Bahasa dan Faktor Penyebabnya}

Kelompok soal tersulit kedua menurut persepsi mahasiswa adalah kelompok soal Tata Bahasa. Secara gramatikal, bahasa Jepang memang jauh berbeda dengan bahasa Indonesia. Dalam bahasa Jepang terdapat banyak partikel yang fungsinya bermacam-macam. Ciri khas lainnya adalah predikat kalimat diletakkan di akhir kalimat dengan struktur subjek-objek-predikat (S-O-P) untuk kalimat transitif (Sutedi, 2008). Perbedaan karakteristik antara bahasa Jepang dengan bahasa Indonesia membuat pembelajar bahasa Jepang di Indonesia pasti sedikit banyak merasa kesulitan untuk menguasai tata bahasa Bahasa Jepang.

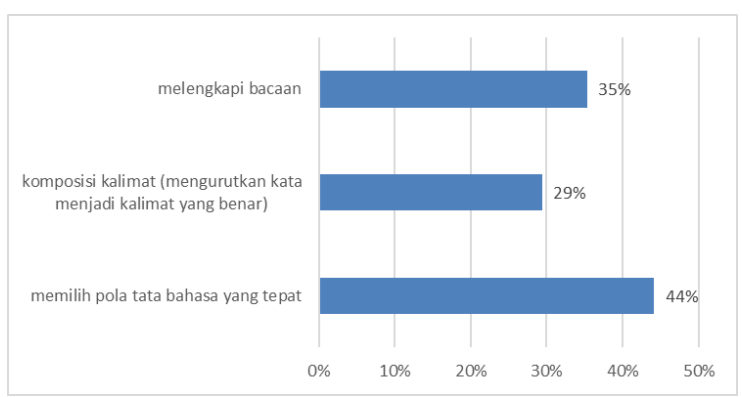

Bagan 4. Bagian Tersulit dalam

Kelompok Soal Tata Bahasa (sumber: data penelitian tahun 2019)
Dalam kelompok soal Tata Bahasa, dari tiga jenis soal, yaitu melengkapi bacaan, komposisi kalimat, dan memilih pola tata bahasa yang tepat, jenis soal yang disebutkan terakhir adalah yang tersulit bagi para mahasiswa. Akan tetapi, perbedaan jumlah antara ketiganya tidak begitu jauh seperti yang dapat dilihat pada Bagan 4.

Terdapat beberapa faktor penyebab kesulitan mengerjakan soal tata bahasa menurut persepsi mahasiswa. Di antaranya adalah banyak terdapat pola tata bahasa yang belum pernah dipelajari sebelumnya. Kendala ini dirasakan oleh sebanyak $53 \%$ responden. Di samping itu, terdapat $18 \%$ responden mengungkapkan bahwa kesulitan disebabkan oleh faktor seperti kurangnya pemahaman tentang fungsi partikel ataupun perubahan kata kerja pada pola tata bahasa tertentu.

Selain partikel (joshi), banyak mahasiswa terkendala dalam memahami fungsi dan makna konjungsi (setsuzokushi) serta kata kerja bantu (jodoushi) dalam bahasa Jepang level N3/N2/N1, karena jenisnya sangat bervariasi. Meski banyak bentuk atau fungsi konjungsi/kata kerja bantu yang terkesan mirip, namun sebetulnya terdapat perbedaaan satu sama lain. Kemiripan bentuk maupun fungsi ini juga menjadi salah satu faktor penyebab kesulitan yang diungkapkan oleh sebanyak $18 \%$ responden.

Sementara itu, faktor banyaknya kosakata/huruf kanji yang belum diketahui maknanya disebutkan oleh sebanyak $26 \%$ responden. Tidak dapat dipungkiri, apabila peserta tidak memahami arti/makna kosakata dalam soal, maka yang bersangkutan pasti tidak dapat menentukan jawaban yang tepat dari soal tersebut karena dia tidak dapat memahami makna kalimat itu. 


\section{Kesulitan Pada Kelompok Soal Kosakata dan Faktor Penyebabnya}

Kesulitan pada kelompok soal kosakata dirasakan oleh sebanyak $42 \%$ responden. Pada kelompok soal ini, soal sinonim kata dan penggunaan kosakata yang tepat dalam kalimat menjadi kendala yang paling banyak dirasakan oleh responden, yaitu masing-masing sebesar $44 \%$ dan 38\%. Sementara itu, kesulitan pada soal cara membaca kanji dan soal ejaan hanya dirasakan oleh masing-masing $21 \%$ responden seperti yang dapat dilihat pada Bagan 5 berikut ini.

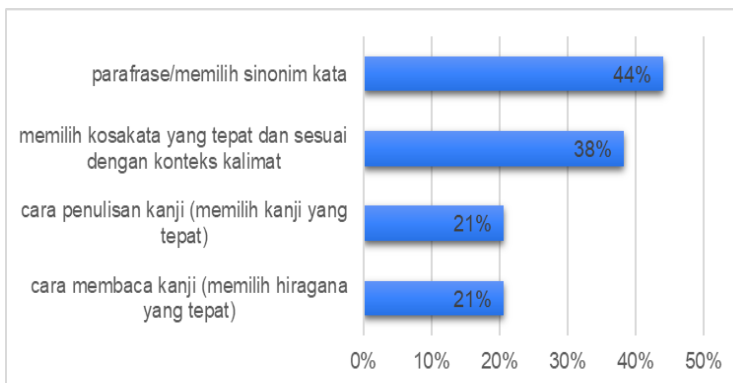

Bagan 5. Bagian Tersulit dalam

Kelompok Soal Kosakata (Moji-goi)

(sumber: data penelitian tahun 2019)

Jika dianalisis lebih jauh dari bagian soal yang dianggap sulit, penguasaan kosakata mahasiswa masih terbatas pada penguasaan terhadap cara baca kanji maupun arti kanji. Akan tetapi, pemahaman mereka tentang makna sebuah kata dan penggunaannya dalam kalimat masih kurang, sehingga kesulitan pada kelompok soal Kosakata terutama dirasakan pada bagian soal parafrase dan bagian penerapan kosakata dalam sebuah kalimat.

Berdasarkan persepsi mahasiswa, terdapat beberapa faktor penyebab kesulitan yang dirasakan. Faktor yang paling banyak (47\%) diungkapkan oleh mahasiswa adalah kesulitan yang disebabkan karena kosakata yang muncul dalam soal belum pernah dipelajari sebelumnya. Selanjutnya, sebanyak 32\% responden mengungkapkan bahwa kesulitan disebabkan karena merasa belum pernah mempelajari kanji yang muncul dalam soal.

Berkaitan dengan soal cara membaca kanji, kesulitan disebabkan karena peserta lupa cara baca onyomi maupun kunyomi dari kanji yang muncul dalam soal. Faktor ini diutarakan oleh $12 \%$ responden. Terdapat pula faktor penyebab lain, yang diungkapkan oleh $18 \%$ responden, yaitu banyaknya bentuk kanji yang mirip, sehingga apabila tidak teliti, peserta ujian akan terkecoh atau bingung menentukan jawaban yang tepat.

\section{Kesulitan pada Kelompok Soal Menyimak dan Faktor Penyebabnya}

Seperti yang telah dipaparkan sebelumnya, kelompok soal Menyimak dianggap sebagai bagian termudah dalam ujian JLPT N3 oleh sebanyak 59\%. Berbanding lurus dengan itu, soal Menyimak hanya dirasakan sulit oleh $12 \%$ responden. Bagian tersulit bagi mahasiswa adalah pada bagian memahami poin utama sebuah ceramah/penjelasan tentang sesuatu (pointo rikail ポイント理解). Bagian tersulit kedua yaitu soal memahami garis besar percakapan secara umum (gaiyou rikail 概 要理 解), dan tersulit ketiga adalah bagian pemahaman berbasis tugas (kadai rikai/課題理解). Tiga bagian soal tersebut memang menguji pemahaman peserta tentang isi ceramah dan inti pembicaraan dalam bahasa Jepang.

Berbeda dengan tiga jenis soal tersebut, dua bagian soal lainnya bertujuan untuk melihat apakah peserta ujian mampu memilih ujaran yang tepat sesuai dengan konteks kalimat. Dengan kata lain, dua bagian itu menguji kemampuan berbicara para peserta. Bagian soal memberikan respon dengancepat (sokuji outo/ 即 時 応答) hanya dirasakan sulit oleh 3\% responden. Sementara itu, tidak ada satupun responden yang menganggap sulit bagian ekspresi ujaran (hatsuwa hyogen/発話表 現) dimana peserta diuji apakah mereka mampu memilih ujaran yang tepat sesuai 
dengan konteks dalam gambar. Rendahnya jumlah siswa yang merasakan kesulitan pada bagian ini mungkin disebabkan karena kurikulum pendidikan pada Program Studi DIII Bahasa Jepang Sekolah Vokasi dirancang agar porsi perkuliahan praktik lebih besar dari pada teori. Tujuan pendidikan di Sekolah Vokasi menekankan kepada kemampuan berkomunikasi secara aktif, sehingga dalam perkuliahan mahasiswa sering berlatih percakapan dalam berbagai situasi, dari situasi sehari-hari hingga situasi di tempat kerja.

Berdasarkan persepsi mahasiswa, kesulitan dalam mengerjakan soal Menyimak terutama disebabkan oleh faktor kecepatan berbicara native speaker dalam dialog pada soal. Meskipun sebetulnya native speaker berbicara dengan kecepatan normal dalam soal Menyimak, namun bagi beberapa mahasiswa dianggap terlalu cepat. Hal ini mungkin berkaitan dengan faktor penyebab kesulitan lain, yaitu faktor penguasaan kosakata yang masih kurang dan faktor penggunaan ragam informal dalam percakapan pada soal yang berupa dialog. Apabila mahasiswa tidak familiar dengan kosakata ataupun ragam bahasa pada soal, maka dialog akan terasa sangat cepat bagi mereka.

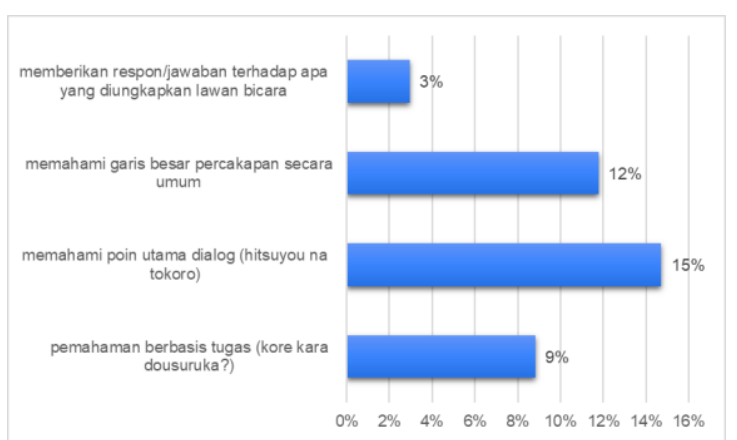

Bagan 6. Bagian Tersulit Dalam Kelompok Soal Menyimak

(sumber: data penelitian tahun 2019)

Sebanyak 24\% mahasiswa juga mengungkapkan pada saat sesi ujian
Menyimak, terkadang mereka kehilangan konsentrasi. Pada saat mereka masih memikirkan jawaban untuk soal sebelumnya, dialog soal berikutnya sudah dimulai. Pada saat seperti itu, mereka tidak dapat menangkap isi dialog karena tidak dapat menyimak dialog dengan baik.

\section{Analisis Faktor Penyebab Kesulitan Mengikuti JLPT N3}

Pada pembahasan sebelumnya, telah dijelaskan tentang jenis soal JLPT N3 yang sulit serta faktor penyebab kesulitan pada masing-masing kelompok soal menurut persepsi mahasiswa. Tabel 4 merupakan rangkuman faktor penyebab kesulitan pada semua kelompok soal JLPT N3.

Tabel 4 menunjukkan 10 faktor penyebab kesulitan yang paling banyak diungkapkan oleh responden. Pada tabel tersebut, dapat kita lihat bahwa terdapat penyebab yang khas dari masing-masing kelompok soal. Akan tetapi, terdapat sebuah persamaan yang mencolok, yaitu kesulitan yang disebabkan karena kurangnya penguasaan kosakata ditemukan pada semua kelompok soal. Oleh karena itu, dapat ditarik kesimpulan bahwa kesulitan yang dirasakan oleh mahasiswa kemungkinan berakar pada penguasaan kosakata yang masih rendah.

Penguasaan mahasiswa terhadap sebuah kata masih terbatas pada cara membaca dan artinya, sedangkan pemahaman terhadap makna dan penerapannya dalam kalimat masih kurang. Selain menambah perbendaharaan kata sebanyakbanyaknya, mahasiswa perlu meningkatkan pemahaman mereka tentang makna dan penggunaan sebuah kata dalam kalimat agar mampu mengerjakan bagian soal lain (Membaca, Tata Bahasa, dan Menyimak) dengan baik. 
Tabel 4. 10 Faktor Penyebab Kesulitan yang Paling Banyak Diungkapkan oleh Responden.

\begin{tabular}{|c|l|l|c|c|}
\hline No & \multicolumn{1}{|c|}{ Sesi } & \multicolumn{1}{|c|}{ Faktor Penyebab Kesulitan } & Jumlah & Prosentase \\
\hline 1 & Membaca & $\begin{array}{l}\text { tidak menguasai kosakata yang ada dalam bacaan } \\
\text { (makna kosakata maupun kanji) }\end{array}$ & 20 & $59 \%$ \\
\hline 2 & Tata Bahasa & $\begin{array}{l}\text { belum pernah mempelajari pola tata bahasa yang } \\
\text { muncul dalam soal }\end{array}$ & 18 & $53 \%$ \\
\hline 3 & Kosakata & tidak mengenal kosakata yang muncul dalam soal & 16 & $47 \%$ \\
\hline 4 & Membaca & banyak kalimat panjang dan sulit memahami intinya & 13 & $38 \%$ \\
\hline 5 & Menyimak & merasa percakapan terlalu cepat & 12 & $35 \%$ \\
\hline 6 & Kosakata & $\begin{array}{l}\text { belum familiar dengan kanji yang muncul dalam } \\
\text { soal }\end{array}$ & 11 & $32 \%$ \\
\hline 8 & Tata Bahasa & $\begin{array}{l}\text { tidak memahami makna kanji/kosakata yang muncul } \\
\text { dalam soal }\end{array}$ & 9 & $26 \%$ \\
\hline 7 & Membaca & kehabisan waktu & 9 & $26 \%$ \\
\hline 9 & Menyimak & tidak menguasai kosakata yang muncul dalam soal & 8 & $24 \%$ \\
\hline 10 & Menyimak & kurang konsentrasi saat mendengarkan soal & 8 & $24 \%$ \\
\hline
\end{tabular}

(sumber: data penelitian tahun 2019)

\section{KESIMPULAN}

Dari penelitian yang telah dilakukan, dapat disimpulkan bahwa bagi mahasiswa, kendala utama mahasiswa dalam mengikuti ujian JLPT N3 adalah saat mengerjakan soal Membaca (88\%) dan Tata Bahasa (62\%). Sementara itu, kelompok soal kosakata dirasakan sulit oleh $41 \%$ mahasiswa. Sedangkan soal Menyimak merupakan soal yang termudah bagi mahasiswa.

Dari seluruh faktor penyebab yang diungkapkan mahasiaswa, terdapat fakta bahwa penguasaan kosakata merupakan faktor penyebab yang paling menonjol dan dirasakan oleh sebagian besar mahasiswa saat mengerjakan semua kelompok soal JLPT N3, yaitu Membaca, Tata Bahasa, Kosakata, dan Menyimak.

Berdasarkan kesimpulan tersebut, penulis menyampaikan beberapa rekomendasi agar mahasiswa dapat meningkatkan kompetensi bahasa Jepang di level N3, yaitu sebagai berikut:

1. Mahasiswa perlu memper-banyak latihan membaca bacaan dengan berbagai tema, tidak hanya dalam perkuliahan, namun juga di luar perkuliahan (seperti artikel dalam koran atau majalah yang dapat diakses secara daring), karena aktivitas membaca dapat meningkatkan penguasaan kosakata dan tata bahasa seseorang.

2. Meskipun pendidikan vokasi berorientasi kepada penguasa-an kompetensi komunikasi secara aktif (dalam hal ini kompetensi berbicara), dosen perlu mengembangkan metode pembelajaran yang dapat meningkatkan pemahaman mahasiswa tentang makna dan penggunaan kosakata dalam kalimat.

\section{DAFTAR PUSTAKA}

Babaiba, W. (2015). Reading Comprehension Difficulties among EFL Learners: The Case of Third-Year Learners at Nehali Mohamed Secondary School. Master thesis. University of Tlemcen. Retrieved July 2, 2019 from http://dspace.univtlemcen.dz/bitstream/112/7899/1/baba yeba-wahiba.pdf

Cahyono, A.B, \& Syartanti, N.I. (2017). Strategi Belajar Kelolosan Japanese Language Proficiency Test N1 (Studi Kasus Mahasiswa Sastra Jepang). 
Pramasastra: Jurnal Ilmiah Bahasa Sastra dan Pembelajarannya, 4 (1), p. 43-54. Universitas Negeri Surabaya.

Japan Foundation and Japan Educational Exchanges and Services. (2012). Japanese-Language Proficiency Test. Retrieved July 2, 2019 from https://www.jlpt.jp/e/about/purpose.ht $\mathrm{ml}$.

Japan Foundation and Japan Educational Exchanges and Services. (2009). New Japanese-Language Proficiency Test Sample Questions. Retrieved July 2, 2019
https://www.jlpt.jp/e/samples/pdf/N3mondai.pdf.

Rahmawati, D. (2014). Tingkat Kesulitan dalam Jenis Soal Kemampuan Nihongo Nooryoku Shiken (Studi Kasus Mahasiswa Prodi Bahasa Jepang Sekolah Vokasi Universitas Gadjah Mada). Tugas Akhir tidak dipublikasikan. Universitas Gadjah Mada.

Sutedi, D. (2008). Dasar-Dasar Linguistik Bahasa Jepang. Bandung: Humaniora.

Tjandra. S.N. (2014). Sintaksis Jepang. Jakarta: Bina Nusantara. 